\title{
60. Stumpfe Lungenverletzungen
}

\author{
H. CesNIK-Graz/Österreich \\ Blunt Lung Traumas
}

Summary. 1910 blunt injuries of the chest cage are reviewed. In about $20 \%$ of the patients who had suffered a blunt injury of the thorax there was radiological, clinical and in some cases even anatomico-pathological evidence of lung injury. Of blunt lung injuries, contusions of the lung are the most numerous. The chest $\mathrm{X}$-ray in such cases shows small spots or larger patches of consolidation, less commonly band-kike shadows, which can be observed immediately after the injury and disappear after one to two weeks.

Blunt lung injuries only rarely require surgical measures and in most cases heal under conservative therapy.

Zusammenfassung. Es wird über 1910 stumpfe Brustkorbverletzungen berichtet. Bei $20 \%$ der Patienten, die ein stumpfes Brustkorbtrauma erlitten hatten, war röntgenologisch, klinisch und in einigen Fällen auch pathologisch-anatomisch eine Verletzung der Lunge eindeutig nachzuweisen. Unter den stumpfen Lungenverletzungen steht die Lungenkontusion zahlenmäBig an erster Stelle. Sie zeigt sich im Röntgenbild durch klein- bis großfleckige, selten streifenförmige Verschattungen, die schon unmittelbar nach dem Trauma zu sehen sind und nach 1-2 Wochen wieder verschwinden.

Die stumpfen Lungenverletzungen zwingen nur selten zu chirurgischen Eingriffen an der Lunge und heilen meist unter konservativer Behandlung aus.

\section{Stumpfe Lungentraumen}

M. JEkıć-Beograd/Jugoslawien

\section{Blunt Trauma of the Lung}

Summary. This is a detailed discription of the most important aspects of first aid given in hospitals to patients with serious lung traumata. Between 1965 and 1970534 patients with serious thoracic and lung injuries were treated at the hospital in question.

Zusammenfassung. Es werden die wichtigsten Details für die Erstversorgung der schweren Lungentraumen im Krankenhaus geschildert. Im eigenen Krankengut wurden in den Jahren 1965-1970 534 Patienten mit schweren Verletzungen des Thorax und der Lunge behandelt. 